Check for updates

Cite this: RSC Adv., 2019, 9, 40109

\title{
The characterization of soybean germ oil and the antioxidative activity of its phytosterols
}

\begin{abstract}
Jingnan Chen, (D) * Guiyun Tang, Jinfen Zhou, Wei Liu and Yanlan Bi*
The aim of this study was to characterize the composition of soybean germ and its oil from Northeast (NESG) and Shandong Province (SD-SG) of China with a focus on the composition of fatty acids and phytosterols as well as physicochemical properties. The results show that the average contents of water, protein, crude fat, crude fiber and ash of NE-SG and SD-SG were $8.23 \pm 0.11 \%, 40.47 \pm 0.10 \%, 11.65 \pm$ $0.14 \%, 6.20 \pm 0.09 \%$ and $4.79 \pm 0.14 \%$, respectively. The major fatty acids of the two soybean germ oils were linoleic acid (NE-SGO, 55.45\%; SD-SGO, 52.15\%), alpha-linolenic acid (NE-SGO, 16.21\%; SD-SGO, 18.50\%), palmitic acid (NE-SGO, 12.59\%; SD-SGO, 11.40\%) and oleic acid (NE-SGO, 9.87\%; SD-SGO, $10.96 \%$ ). The soybean germs were rich in phytosterols (NE-SGO, 3168 mg/100 g oil; SD-SGO, 3010 mg/ $100 \mathrm{~g}$ oil) consisting of $\beta$-sitosterol, $\Delta 7$-stigmastenol, campesterol, stigmastanol, and citrostadienol. The antioxidant ability of soybean germ phytosterols was evaluated using $\mathrm{DPPH}^{*}$ and $\mathrm{OH}^{*}$ radical scavenging assays, $\beta$-carotene protection assay and a heating oil system. The results demonstrated that soybean germ phytosterols had better antioxidant ability in oil systems than in non-oil systems. The antioxidant ability of these phytosterols was temperature- and time-dependent since it was more effective at lower temperatures $\left(60^{\circ} \mathrm{C}\right)$ with longer times as compared to higher temperatures $\left(120^{\circ} \mathrm{C}\right.$ and $\left.180^{\circ} \mathrm{C}\right)$ with shorter times. These results prove that soybean germ phytosterols could be used as antioxidants in preventing lipid oxidation in foods stored at a low temperature for a long time.
\end{abstract}

Received 25th October 2019 Accepted 13th November 2019 DOI: 10.1039/c9ra08771k

rsc.li/rsc-advances

\section{Introduction}

Soybean is an important legume crop. As a by-product in the production of soybean oil, soybean germ accounts for $2-2.5 \%$ of soybean seeds. ${ }^{1}$ Currently, soybean germ is not commonly used for human consumption but is mainly used an ingredient in animal feeds. ${ }^{2}$ It is rich in various nutrients including polyunsaturated fatty acids, protein, phytosterols, ${ }^{3}$ tocopherols, ${ }^{4}$ isoflavones and saponins. ${ }^{5}$ In this regard, recent research has demonstrated that soybean germ protein could decrease weight due to body fat and increase the muscle weight of hind limbs in experimental animals, ${ }^{6}$ while soybean germ oil could reduce blood cholesterol ${ }^{7}$ and prevent UVB-induced cutaneous erythema. $^{\mathbf{8}}$

It is worth noting that soybean germ oil is rich in phytosterols $(6.98 \%)$ as compared with other vegetable oils., Phytosterols have the ability to lower serum cholesterol and triacylglycerols, ${ }^{\mathbf{1 0 , 1 1}}$ and possess anti-inflammatory, anti-aging, anti-tumor and other physiological properties. ${ }^{\mathbf{1 2 , 1 3}}$ Recent research has shown that soybean germ phytosterols are effective in reducing serum and hepatic cholesterol as compared to whole-soy phytosterols. ${ }^{\mathbf{1 4}}$ Moreover, these phytosterols may

College of Food Science and Technology, Henan University of Technology, Zhengzhou, 450001, China. E-mail: chenjingnan813@126.com; bylzry@l26.com; Fax: +86-37167758022; Tel: +86-371-67758022 function as natural antioxidants due to their ease of formation and relative stability of the corresponding allylic free radicals. ${ }^{15,16}$

Northeast China and Shandong Province are the two places where soybean grows the most in China. However, information about the chemical compositions of soybean germ and its oil from these locations is scarce. The present study was undertaken to (i) characterize the chemical compositions of soybean germ and its oil from Northeast China (NE-SG) and Shandong Province (SD-SG), and (ii) investigate the antioxidant activity of phytosterols derived from NE-SG in various oxidation systems.

\section{Materials and methods}

\subsection{Chemicals and reagents}

NE-SG and SD-SG were purchased from Riotto Botanical Co. Ltd. (Shanxi, China) and stored at $-10{ }^{\circ} \mathrm{C}$ before analysis. Soybean oil (no exogenous antioxidants) was purchased from a local supermarket. 5- $\alpha$-Cholestan-3 $\beta$-ol (95\%), N,O-bis (trimethylsilyl) trifluoroacetamide (BSTFA) $+1 \%$ trimethylchlorosilane (TMCS), fatty acid methyl esters, pancreatic lipase, and tocopherols $(\alpha-, \beta-, \gamma-, \delta$-isomers) were obtained from Sigma-Aldrich Co. (St. Louis, MO, USA). Silica used for TLC plate preparation was obtained from Qingdao Ocean Chemical Factory (Qingdao, China). 


\subsection{Chemical compositions of soybean germ}

Soybean germ was thoroughly ground and passed through an 80-mesh sieve. Moisture, crude protein, crude fiber, crude oil and total ash were determined according to the methods of AOAC. ${ }^{17}$ The amino acid composition of soybean germ protein was determined according to the method of Spackman et al. ${ }^{\mathbf{1 8}}$ using a Beckman amino acid analyzer (Model 119 CL).

\subsection{Physicochemical properties of soybean germ oil}

Soybean germ oil was extracted using petroleum ether at a solvent ratio of $4: 1\left(\mathrm{~mL} \mathrm{~g}^{-1}\right)$ in a Soxhlet apparatus for $8 \mathrm{~h}$. After the extraction, the solvent was evaporated under vacuum. The obtained oil was flushed with nitrogen and stored in a freezer $\left(-5{ }^{\circ} \mathrm{C}\right)$ for further analyses. Iodine value, saponification value, peroxide value $\left(\mathrm{mmol} \mathrm{kg}^{-1}\right)$, acid value $(\mathrm{mg} \mathrm{KOH} / \mathrm{g}$ oil), phospholipids and unsaponifiable matter (\%) were determined according to the recommended methods of AOAC. ${ }^{19}$ Tocopherols in crude soybean germ oil were determined using high-performance liquid chromatography (HPLC) as described by Oomah et al. with some modifications. ${ }^{20}$

\subsection{Fatty acid composition and triacylglycerols analysis}

Soybean germ oil was methylated and the analysis of fatty acid methyl esters (FAME) was performed on a gas chromatograph (GC) (Agilent 6890N) equipped with a flame ionization detector (FID) and a BPX-70 capillary column $(30 \mathrm{~m} \times 0.32 \mathrm{~mm}$, film thickness of $0.25 \mu \mathrm{m}$ ) (Agilent Technologies Co., Ltd.). ${ }^{21}$ Soybean germ oil ( $50 \mathrm{mg}$ ) was dissolved in $1 \mathrm{~mL}$ hexane followed by TLC analysis in a solvent mixture of hexane, ethyl ether and acetic acid in a ratio of $80: 20: 2, \mathrm{v} / \mathrm{v} / \mathrm{v}$. The bands of triacylglycerols (TG) and free fatty acids (FFA) were scratched off the plate followed by methylation. Resultant FAME was subjected to GC analysis. 1,3-Specific pancreatic lipase was employed for sn-2 fatty acid composition analysis according to the AOCS method. ${ }^{20}$ The hydrolyzate was separated on a TLC plate using a solvent mixture of hexane, diethyl ether and acetic acid in a ratio of $70: 30: 1, \mathrm{v} / \mathrm{v} / \mathrm{v}$. Monoglycerides (MG) were scratched off the plate and extracted with diethyl ether. After methylation, FAME was subjected to GC for sn-2 fatty acid composition analysis.

\subsection{Phytosterol analysis}

Phytosterols of soybean germ were determined according to the AOCS Ch 6-91 method with slight modification. ${ }^{22}$ Soybean germ oil ( $0.2 \mathrm{~g})$ was saponified with $1 \mathrm{M}$ potassium hydroxide $(2 \mathrm{~mL})$ in ethanol $\left(90{ }^{\circ} \mathrm{C}, 90 \mathrm{~min}\right)$. The unsaponifiable fraction was extracted three times with $30 \mathrm{~mL} n$-hexane. The solvent was removed and crude phytosterols were purified on a TLC plate using a solvent mixture of hexane : ethyl ether : acetic acid (70:30:2, v/v/v). Then, $800 \mu \mathrm{L} 99 \%$ BSTFA + 1\% TMCS was added and the mixture was heated at $60{ }^{\circ} \mathrm{C}$ for 1 hour. After derivatization, phytosterols were extracted using $800 \mu \mathrm{L} n$ hexane and then dried on anhydrous sodium sulfate. Individual and total soybean germ phytosterols were analyzed in a gas chromatography system (Agilent Technologies Co., Ltd.,
Southfield, $7890 \mathrm{~N})(\mathrm{HP}-5,30 \mathrm{~m} \times 320 \mu \mathrm{m} \times 0.25 \mu \mathrm{m})$. The column temperature was kept at $285{ }^{\circ} \mathrm{C}$ for $20 \mathrm{~min}$. The carrier

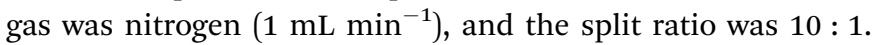
The injection and detection temperatures were set at $300{ }^{\circ} \mathrm{C}$ and $360{ }^{\circ} \mathrm{C}$, respectively. $5-\alpha$-Cholestan- $3 \beta$-ol was used as an internal standard for quantification.

\subsection{Preparation of phytosterols for antioxidant assay}

NE-SG was used for the antioxidant assay because it had the same individual phytosterols but the phytosterols content was a little higher than that from SD-SG. In brief, soybean germ oil was saponified in $1 \mathrm{M} \mathrm{NaOH}$ in $95 \%$ ethanol under nitrogen gas. The unsaponifiable matter was extracted using $n$-hexane. The extraction solvent was evaporated and the obtained crude phytosterol extracts were dissolved in anhydrous ethanol in a ratio of $1: 8$ (extracts/ethanol) for recrystallization $\left(-4{ }^{\circ} \mathrm{C}, 8\right.$ h). The snowflake white crystal phytosterols were obtained with the purity over $95 \%$.

\subsection{1,1-Diphenyl-2-picrylhydrazyl (DPPH) radical scavenging assay}

The $\mathrm{DPPH}^{*}$ radical scavenging ability of soybean germ phytosterols was carried out according to the method described by Morales and Jimenez-Perez. ${ }^{23}$ Briefly, $2 \mathrm{~mL}$ of 800, 1200, 1600, 2000, $10000 \mu \mathrm{g} \mathrm{mL}^{-1}$ soybean germ phytosterols/ethanol solution were mixed with $2 \mathrm{~mL}$ of freshly prepared $0.10 \mathrm{mM}$ $\mathrm{DPPH}^{\circ}$ ethanol solution. The solution was incubated at $25^{\circ} \mathrm{C}$ for $30 \mathrm{~min}$ with vigorous shaking. After centrifugation, $1 \mathrm{~mL}$ of supernatant was transferred to a $1.5 \mathrm{~mL}$ plastic cuvette and the absorbance $A_{i}$ was measured at $517 \mathrm{~nm}$. The absorbance of $0.10 \mathrm{mM} \mathrm{DPPH}^{*}$ ethanol solution was also measured and denoted as $A_{0}$. The absorbances of $2 \mathrm{~mL}$ soybean germ phytosterols $\left(800,1200,1600,2000,10000 \mu \mathrm{g} \mathrm{mL}{ }^{-1}\right)$ in $2 \mathrm{~mL}$ ethanol solution without $\mathrm{DPPH}^{*}$ were also determined $\left(A_{j}\right)$ in order to avoid the color of phytosterol itself in the absorbance. The inhibition percentage of the $\mathrm{DPPH}^{*}$ radical was calculated using the following equation: inhibition percentage $(\%)=[1-$ $\left.\left(A_{i}-A_{j}\right) / A_{0}\right] \times 100$. The $\mathrm{DPPH}^{*}$ radical scavenging ability of BHT and $V_{\mathrm{C}}$ were also determined for comparison.

\subsection{Hydroxyl $\left(\mathrm{OH}^{*}\right)$ radical scavenging assay}

The hydroxyl radical scavenging assay was determined according to the method described by Chen and Huang. ${ }^{24}$ In brief, 50 $\mu \mathrm{LFSO}_{4}\left(1.8 \mathrm{mmol} \mathrm{L}^{-1}\right), 50 \mu \mathrm{L}$ salicylic acid $\left(1.8 \mathrm{mmol} \mathrm{L}^{-1}\right)$ and $50 \mu \mathrm{L} \mathrm{H}_{2} \mathrm{O}_{2}(0.3 \%)$ were reacted for 5 minutes at $37^{\circ} \mathrm{C}$ and the absorbance $A_{0}$ was measured at $510 \mathrm{~nm}$. Then $50 \mu \mathrm{L}$ soybean germ phytosterols at various concentrations $\left(300-700 \mu \mathrm{g} \mathrm{mL} \mathrm{m}^{-1}\right.$, $95 \%$ ethanol) were added to the prepared solution. The mixture was incubated at $37{ }^{\circ} \mathrm{C}$ for $35 \mathrm{~min}$ and the UV absorbance was measured at $510 \mathrm{~nm}\left(A_{1}\right)$. The percentage of inhibition was calculated as follows: scavenging percentage $(\%)=\left[1-\left(A_{1}-\right.\right.$ $\left.\left.A_{2}\right) / A_{0}\right] \times 100$, where $A_{2}$ was the absorbance of blank control solution, and $V_{\mathrm{C}}$ was measured for comparison. 


\section{$2.9 \quad \beta$-Carotene protection assay}

The protective effect of soybean germ phytosterols against the oxidization of $\beta$-carotene was evaluated according to the method developed by Miller. ${ }^{25}$ The mixture containing $0.8 \mathrm{mg}$ of crystalline $\beta$-carotene, $20 \mu \mathrm{L}$ of linoleic acid, and $200 \mu \mathrm{L}$ of commercial surfactant Tween 40 (polyoxyethylene sorbitan monopalmitate), was dissolved in $20 \mathrm{~mL}$ of reagent-grade chloroform and mixed well. After the solvent was evaporated at $40{ }^{\circ} \mathrm{C}$, a viscous oil was obtained and then $200 \mathrm{~mL}$ of $\mathrm{O}_{2}$ saturated osmosed water was added immediately and vigorously shaken for $2 \mathrm{~min}$. Each $10 \mathrm{~mL}$ of the prepared emulsion was mixed with $400 \mu \mathrm{L}$ of test compounds $\left(200-600 \mathrm{mg} \mathrm{mL}^{-1}\right.$, $80 \%$ ethanol). The solution was incubated at $50{ }^{\circ} \mathrm{C}$ under exposure to daylight for $60 \mathrm{~min}$ with shaking. The absorbance of the reaction mixture was monitored at $470 \mathrm{~nm}$. The protective effect of soybean germ phytosterols was expressed as the percentage of $\beta$-carotene protection against bleaching, which was calculated using the following equation: percent protection $=\left[1-\left(A_{60}^{*}-A_{0}^{*}\right) /\left(A_{60}-A_{0}\right)\right] \times 100 .\left(A_{0}\right.$ for the control solution and $A_{0}^{*}$ for the sample mixture were taken immediately on the addition of emulsion to the phytosterol solution; $A_{60}$ and $A_{60}^{*}$ were measured with the control and sample mixture and incubated for $60 \mathrm{~min}$, respectively). The protective activity of BHT was examined for comparison.

\subsection{Antioxidant in soybean oil assay}

Different doses of soybean germ phytosterols (200, 400, 600, $800,1000 \mathrm{mg} \mathrm{kg}^{-1}$ ) were added to soybean oil and shaken well. The initial indexes of soybean oil were measured and presented as follows: acid value, $0.24 \pm 0.12 \mathrm{mg} \mathrm{KOH} / \mathrm{g}$; peroxide value, 4.9 $\pm 0.20 \mathrm{mmol} \mathrm{kg}{ }^{-1}$; anisidine value, $3.2 \pm 0.34$; tocopherol content, $99.96 \pm 0.73 \mathrm{mg} / 100 \mathrm{~g}$ oil; phytosterol content, 320.99 $\pm 0.49 \mathrm{mg} / 100 \mathrm{~g}$ oil. The effects of different dosages of soybean germ phytosterols on the rancidity of soybean oil were investigated by evaluation of the changes in the acid value (AV), peroxide value (POV) and anisidine value ( $p$-AnV) of the oil system at different temperatures $\left(60,120\right.$ and $\left.180^{\circ} \mathrm{C}\right)$. The $\mathrm{AV}$, POV and $p$-AnV were determined according to the AOCS method. ${ }^{26}$

\subsection{Statistical analysis}

Experimental results were expressed as the mean value \pm standard deviation (SD) $(n=3)$. Differences were considered statistically significant at $p<0.05$. Statistical analysis was conducted using SPSS software.

\section{Results and discussion}

\subsection{Chemical composition of soybean germ}

The chemical composition of soybean germ is presented in Table 1 . The results show that water, protein, crude fat, crude fiber and ash of NE-SG and SD-SG were $8.63 \pm 0.10 \%$ and $7.84 \pm$ $0.12 \%, 39.77 \pm 0.11 \%$ and $41.17 \pm 0.08 \%, 11.67 \pm 0.13 \%$ and $11.63 \pm 0.14 \%, 6.18 \pm 0.10 \%$ and $6.21 \pm 0.07 \%, 4.76 \pm 0.15 \%$ and $4.82 \pm 0.13 \%$, respectively. The protein contents in NE-SG and SD-SG were similar to that in soybean (36-40\%) but
Table 1 Chemical compositions of soybean germ ${ }^{a}$

\begin{tabular}{lll}
\hline & \multicolumn{2}{l}{ Value $(\%)$} \\
\cline { 2 - 3 } Constituent & NE-SG & SD-SG \\
\hline Moisture & $8.63 \pm 0.10$ & $7.84 \pm 0.12$ \\
Crude protein & $39.77 \pm 0.11$ & $41.17 \pm 0.08$ \\
Crude oil & $11.67 \pm 0.13$ & $11.63 \pm 0.14$ \\
Crude fiber & $6.18 \pm 0.10$ & $6.21 \pm 0.07$ \\
Crude ash & $4.76 \pm 0.15$ & $4.82 \pm 0.13$ \\
Others & 28.99 & 28.33
\end{tabular}

${ }^{a}$ Values are means $\pm \mathrm{SD}, n=3$. NE-SG means soybean germ from Northeast China, SD-SG means the soybean germ from Shandong Province of China.

higher than that in wheat germ $(34.92 \%) .{ }^{27}$ The crude fat contents were lower than that in corn germ $(30.70 \%)^{28}$ and soybean $(20.00 \%)$, but similar to that in wheat germ $(10.74 \%){ }^{27}$ In addition, other components in NE-SG and SD-SG were similar. The results were in agreement with those described by Yu et al. ${ }^{3}$ indicating that the origin and varieties had little effect on the composition of soybean germ.

Table 2 shows the amino acid composition of NE-SG and SDSG expressed as g/100 g. Aspartic acid (14.58, 14.33) (g/100 g) and glutamic acid $(14.09,14.09)$ (g/100 g) were the most abundant amino acids in both NE-SG and SD-SG. The total essential amino acid contents in NE-SG and SD-SG were 36.36 and 36.19

Table 2 Amino acid compositions of soybean germ ${ }^{a}$

\begin{tabular}{|c|c|c|c|}
\hline \multirow[b]{2}{*}{ Amino acid } & \multicolumn{3}{|c|}{$\mathrm{g} / 100 \mathrm{~g}$ protein } \\
\hline & NE-SG & SD-SG & FAO pattern ${ }^{b}$ \\
\hline Isoleucine & 4.78 & 4.86 & 2.80 \\
\hline Leucine & 8.05 & 7.77 & 6.60 \\
\hline Lysine & 6.79 & 7.04 & 5.80 \\
\hline Methionine & 1.51 & 1.46 & \\
\hline Cystine & 1.49 & 1.46 & \\
\hline Total sulfur amino acids & 3.00 & 2.92 & 2.50 \\
\hline Tyrosine & 3.02 & 2.91 & \\
\hline Phenylalanine & 5.42 & 5.34 & \\
\hline Total aromatic amino acids & 8.44 & 8.25 & 6.30 \\
\hline Threonine & 2.26 & 2.19 & 3.40 \\
\hline Tryptophan & 3.02 & 2.91 & 1.10 \\
\hline Valine & 4.53 & 4.62 & 3.50 \\
\hline Histidine & 3.27 & 3.16 & 1.90 \\
\hline Total essential amino acids & 36.36 & 36.19 & 33.90 \\
\hline Arginine & 9.05 & 9.47 & \\
\hline Aspartic acid & 14.58 & 14.33 & \\
\hline Glutamic acid & 14.09 & 14.09 & \\
\hline Serine & 3.77 & 3.89 & \\
\hline Proline & 6.03 & 5.34 & \\
\hline Glycine & 3.70 & 3.64 & \\
\hline Alanine & 3.77 & 4.13 & \\
\hline Total non-essential amino acids & 50.45 & 49.79 & \\
\hline
\end{tabular}

${ }^{a}$ NE-SG means soybean germ from Northeast China, SD-SG means the soybean germ from Shandong Province of China. ${ }^{b}$ FAO/WHO/UNU (1985). 
$\mathrm{g} / 100 \mathrm{~g}$ protein, respectively. Total sulfur amino acids $(3.00 \mathrm{~g} /$ $100 \mathrm{~g})$, total aromatic amino acids $(8.44 \mathrm{~g} / 100 \mathrm{~g})$ and total essential amino acids ( $36.36 \mathrm{~g} / 100 \mathrm{~g}$ ) of NE-SG were higher than those of SD-SG (2.92, 8.25 and $36.19 \mathrm{~g} / 100 \mathrm{~g}$, respectively). Compared with the $\mathrm{FAO} / \mathrm{WHO} / \mathrm{UNU}$ reference values, ${ }^{29}$ all the amino acids of soybean germ from the two regions had higher contents, except for threonine, indicating that the soybean germ protein is a high-quality protein.

\subsection{Physicochemical characteristics of soybean germ oil}

The physicochemical characteristics of crude soybean germ oil are shown in Table 3. The acid value, peroxide value, iodine value, saponification value, phospholipids and total tocopherols of NE-SG oil and SD-SG oil were $2.54 \pm 0.02$ and $6.68 \pm$ $0.04(\mathrm{mg} \mathrm{KOH} / \mathrm{g}), 5.49 \pm 0.09$ and $5.75 \pm 0.10\left(\mathrm{mmol} \mathrm{kg}^{-1}\right)$, $125.62 \pm 0.17$ and $126.68 \pm 0.21\left(\mathrm{~g} \mathrm{I}_{2} / 100 \mathrm{~g}\right.$ oil), $181.32 \pm 0.15$ and $182.16 \pm 0.12,1.88 \pm 0.07$ and $2.71 \pm 0.09$ (\%), 1930 and 745 ( $\mathrm{mg} / 100 \mathrm{~g})$, respectively. Among all of the determination indexes, the acid values of NE-SG oil and SD-SG oil had the most significant differences, followed by the tocopherol and phospholipid contents. The saponification values and unsaponifiable matter of NE-SG oil and SD-SG oil were similar to those

Table 3 Physicochemical properties of crude soybean germ oil ${ }^{a}$

\begin{tabular}{lll}
\hline & \multicolumn{2}{l}{ Values } \\
\cline { 2 - 3 } Properties & NE-SG oil & SD-SG oil \\
\hline Acid value $(\mathrm{mg} \mathrm{KOH} / \mathrm{g})$ & $2.54 \pm 0.02$ & $6.68 \pm 0.04$ \\
Peroxide value $\left(\mathrm{mmol} \mathrm{kg}{ }^{-1}\right)$ & $5.49 \pm 0.09$ & $5.75 \pm 0.10$ \\
Iodine value $\left(\mathrm{g} \mathrm{I}_{2} / 100 \mathrm{~g}\right.$ oil) & $125.62 \pm 0.17$ & $126.68 \pm 0.21$ \\
Saponification value & $181.32 \pm 0.15$ & $182.16 \pm 0.12$ \\
Unsaponifiable matters $(\%)$ & $7.12 \pm 0.13$ & $6.45 \pm 0.13$ \\
Phospholipids $(\%)$ & $1.88 \pm 0.07$ & $2.71 \pm 0.09$ \\
Total tocopherols $(\mathrm{mg} / 100 \mathrm{~g})$ & 1930 & 745
\end{tabular}

${ }^{a}$ NE-SG means soybean germ from the Northeast China, SD-SG means the soybean germ from Shandong Province of China. determined by $\mathrm{Yu}$ et al. ${ }^{3}$ but the total tocopherols were both significantly higher (251.84-317.72 mg/100 g). These differences might be attributable to the variety of soybean germ, breeding conditions, storage time and conditions after harvesting. It was noticed that the content of unsaponifiable matter of soybean germ (NE-SG oil, $7.12 \pm 0.13 \%$; SD-SG oil, $6.45 \pm 0.13 \%$ ) was particularly higher as compared to other oilseeds, indicating that soybean germ was an excellent natural source of phytosterols.

\subsection{Fatty acid composition and triglyceride profile}

The comparison of the fatty acid composition of total fatty acids, free fatty acids and fatty acids in the triglycerides of NESG oil and SD-SG oil is shown in Table 4. Linoleic acid was the major fatty acid (NE-SG oil, 55.45\%; SD-SG oil, 52.15\%) of the total fatty acids (TFA), followed by alpha-linolenic acid (NE-SG oil, 16.21\%; SD-SG oil, 18.50\%), palmitic acid (NE-SG oil, 12.59\%; SD-SG oil, 11.40\%), and oleic acid (NE-SG oil, 9.87\%; SD-SG oil, 10.96\%). It was interesting that the alpha-linolenic acid content in soybean germ oil was higher than that of other usual vegetable oils (soybean oil, 6.88\%; corn oil, 1.12\%; sunflower seed oil, $0.12 \%$; peanut oil, $0.06 \%) .{ }^{30,31}$ The ratio of unsaturated fatty acid to saturated fatty acid exceeded five (NESG oil, 5.10; SD-SG oil, 5.26). Jaselskis et al. reported that soybean oil contained linoleic acid (53.66\%), oleic acid (23.18\%), palmitic acid (10.38\%), alpha-linolenic acid $(6.16 \%)$, and stearic acid (4.33\%). ${ }^{32}$ The fatty acid composition of triacylglycerols (TG-FA) and free fatty acids (FFA) both had the same trend with total fatty acid profile. Moreover, we found that significant differences existed between individual TG-FA contents and unsaturated fatty acids (UFAs)/saturated fatty acids (SFAs) ratios of NE-SG oil (3.71) and SD-SG oil (2.12). Simultaneously, SFAs in triacylglycerols of SD-SG and NE-SG oil were higher as compared with TFA.

Linoleic acid was the major fatty acid in the sn-2 in TG, accounting for about $70 \%$, followed by alpha-linolenic acid and oleic acid Table 5. Arachidic acid and eicosenoic acid were not

Table 4 Fatty acid compositions of soybean germ oil ${ }^{a}$

\begin{tabular}{|c|c|c|c|c|c|c|}
\hline Fatty acid & NE-SG oil & SD-SG oil & NE-SG oil & SD-SG oil & NE-SG oil & SD-SG oil \\
\hline Stearic acid & 3.27 & 4.01 & 3.38 & 8.11 & 3.30 & 3.94 \\
\hline Oleic acid & 9.87 & 10.96 & 10.09 & 19.14 & 9.52 & 8.46 \\
\hline Linoleic acid & 55.45 & 52.15 & 51.97 & 38.86 & 52.6 & 46.71 \\
\hline Eicosenoic acid & 0.38 & 0.41 & 0.15 & 0.60 & ND & ND \\
\hline Others & 0.17 & 0.11 & 1.03 & 1.49 & 5.26 & 3.04 \\
\hline SFAs & 16.06 & 15.59 & 20.47 & 31.81 & 17.03 & 21.57 \\
\hline USFAs & 81.91 & 82.02 & 75.92 & 64.15 & 74.67 & 71.18 \\
\hline USFAs/SFAs ratio & 5.10 & 5.26 & 3.71 & 2.12 & 4.38 & 3.30 \\
\hline
\end{tabular}

${ }^{a}$ NE-SG means soybean germ from Northeast China, SD-SG means the soybean germ from Shandong Province of China. SFAs, saturated fatty acids; USFAs, unsaturated fatty acids. ND not detected. 
Table 5 Total and sn-2 main fatty acid compositions of the soybean germ oil ${ }^{a}$

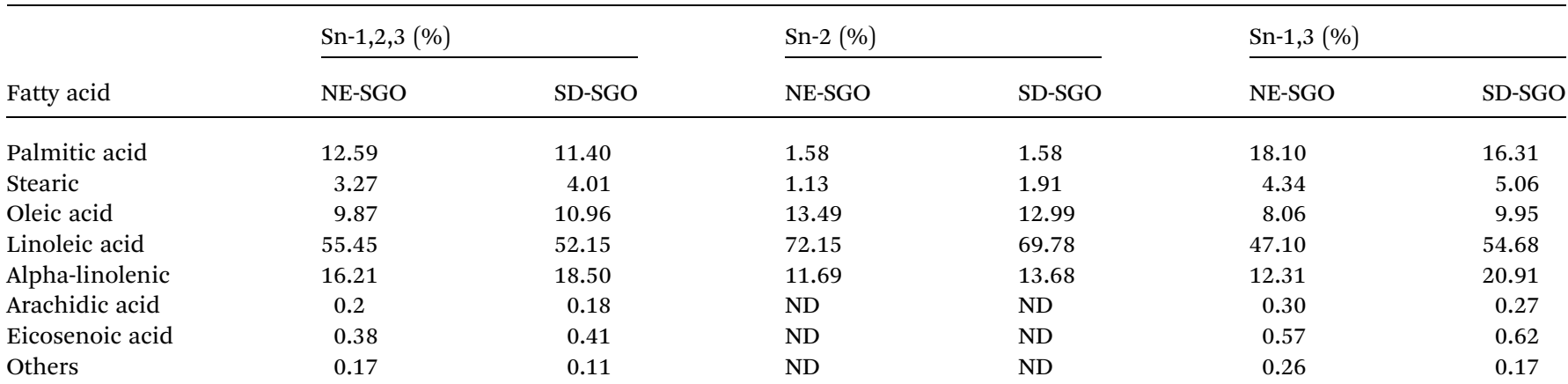

${ }^{a}$ a NE-SG means soybean germ from Northeast China, SD-SG means the soybean germ from Shandong Province of China. Sn-1,3 $=(3 \times$ Sn-1,2,3 Sn-2)/2. ND not detected.

detected on sn-2. In addition, the palmitic acid content on sn-2 (NE-SG oil, 1.58\%; SD-SG oil, 1.58\%) was lower as compared with TFA (NE-SG oil, 12.59\%; SD-SG oil, 11.40\%), indicating that palmitic acid was mainly distributed in sn-1,3, which was also demonstrated by the analysis of fatty acids compositions in sn1,3 (NE-SG oil, $18.10 \%$; SD-SG oil, 16.31\%).

\subsection{Phytosterol content of soybean germ}

The results demonstrated that the phytosterol contents of NESG oil and SD-SG oil were up to 3168 and 3010 (mg/100 g oil), respectively (Fig. 1). Our previous study had shown that soybean germ phytosterols were composed of $\beta$-sitosterol, stigmastenol, campesterol, citrostadienol, stigmasterol and $\Delta 7$-avenasterol. Therein, $\beta$-sitosterol was the most abundant sterol accounting for $1.9 \%$, followed by $\Delta 7$-stigmastenol $(0.31 \%)$ and citrostadienol $(0.24 \%) .{ }^{33}$ In addition, the composition of soybean germ phytosterols was different from soybean phytosterols, which mainly consisted of $\beta$-sitosterol, stigmasterol, campesterol and brassicasterol.

\subsection{Antioxidant activity of soybean germ sterols on DPPH and $\mathrm{OH}^{*}$ scavenging}

A decrease in the absorbance of $\mathrm{DPPH}^{\circ}$ at $517 \mathrm{~nm}$ is always used to evaluate the hydrogen-donating ability of antioxidants. ${ }^{34}$ The scavenging ability of soybean germ phytosterols on $\mathrm{DPPH}^{*}$ is shown in Fig. 2. The results indicate that the $\mathrm{DPPH}^{\circ}$ scavenging ability of soybean germ phytosterols is dose-dependent (5.69$16.94 \%$ ) with the increasing phytosterol concentrations (800$\left.2000 \mu \mathrm{g} \mathrm{mL} \mathrm{m}^{-1}\right)$. However, the effect was not linear; as the concentration continually increased to $10 \mathrm{mg} \mathrm{mL}^{-1}$, the DPPH scavenging percentage was $21.23 \%$, just approximately $4 \%$ higher than that at $2000 \mu \mathrm{g} \mathrm{mL}{ }^{-1}$. The $\mathrm{EC}_{50}$ values $\mathrm{BHT}$ and $V_{\mathrm{C}}$ were $37.38 \pm 0.32 \mu \mathrm{g} \mathrm{mL} \mathrm{m}^{-1}$ and $8.31 \pm 0.15 \mu \mathrm{g} \mathrm{mL} \mathrm{m}^{-1}$, respectively, indicating that soybean germ phytosterols had a weak scavenging ability toward $\mathrm{DPPH}^{\circ}$ as compared with other antioxidants. Farhoosh et al. examined the $\mathrm{DPPH}^{\circ}$ scavenging ability of bene hull sterols, finding that the $\mathrm{EC}_{50}$ value of 4,4dimethyl sterols, 4-methyl sterols and 4-desmethyl sterols were $1.74,6.59$ and $9.89 \mathrm{mg} \mathrm{mL}{ }^{-1}$, respectively. ${ }^{35}$

The hydroxyl radical is one of the representative reactive oxygen species generated in the body. The scavenging ability of soybean germ phytosterols on $\mathrm{OH}^{*}$ is presented in Fig. 3. In the $\mathrm{OH}^{*}$ scavenging assay, the addition of soybean germ phytosterols to the reaction solution induced the ability to remove
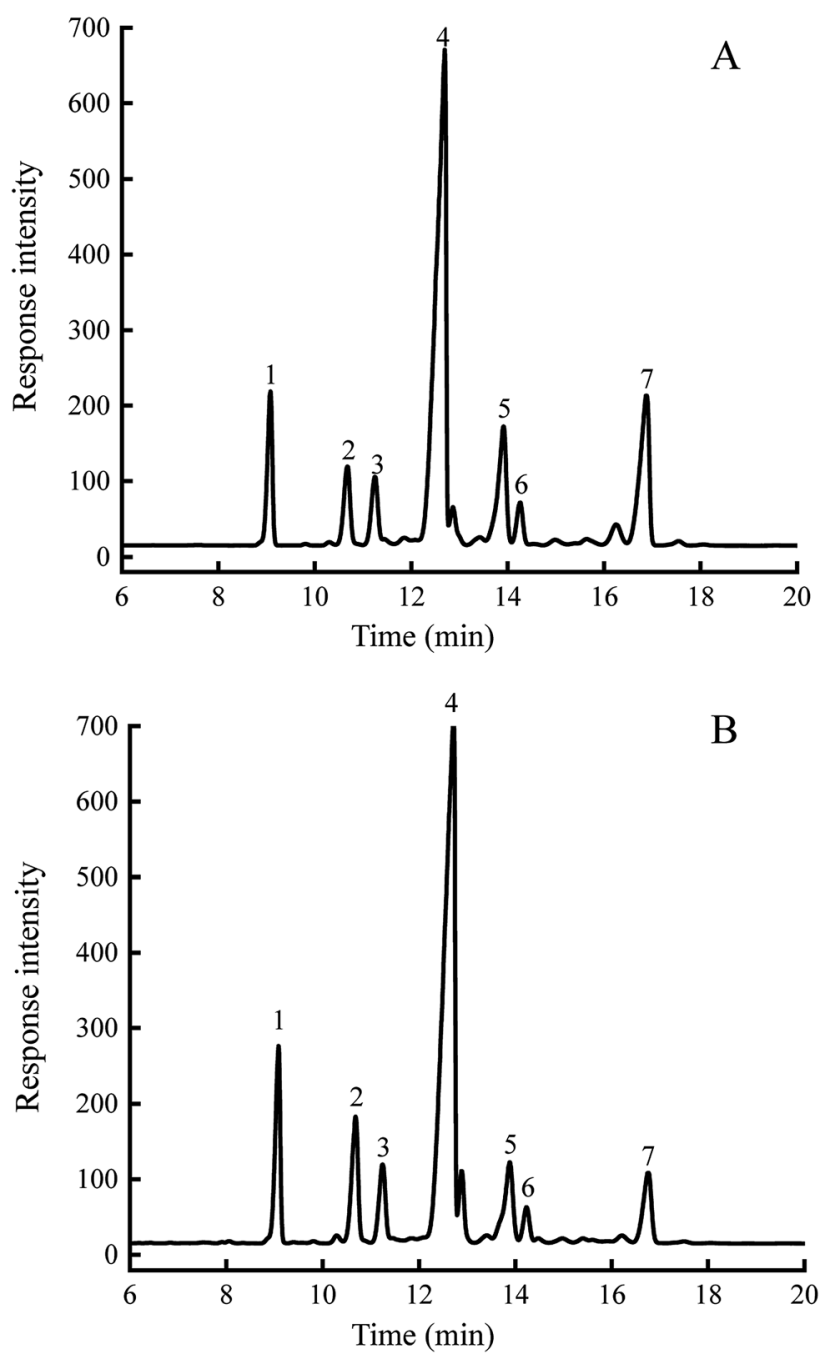

Fig. 1 The phytosterol composition of soybean germ by gas chromatogram. Note: (A) shows the phytosterol composition of NE-SG; (B) shows the phytosterol composition of SD-SG; phytosterol composition: (1) cholestanol (internal standard); (2) campesterol; (3) stigmasterol; (4) $\beta$-sitosterol; (5) stigmastenol; (6) $\Delta 7$-avenasterol; (7); citrostadienol. 


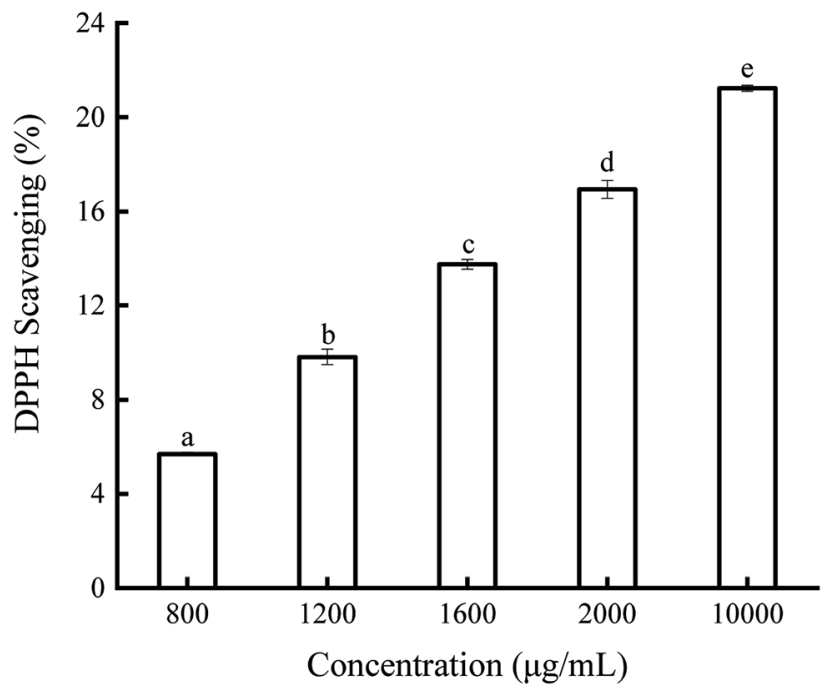

Fig. 2 Elimination effects of soybean germ phytosterols on $\mathrm{DPPH}^{*}$ radicals.

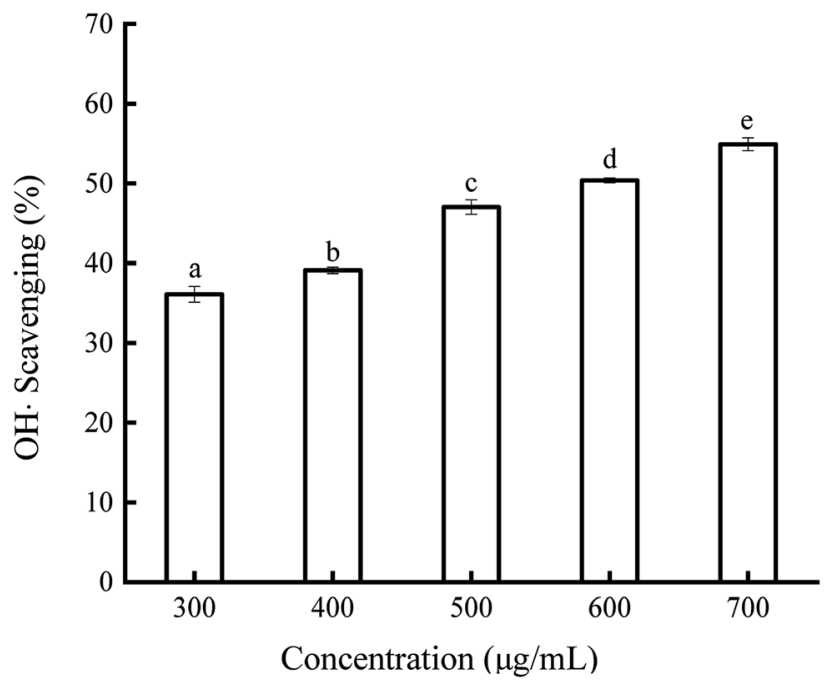

Fig. 3 Elimination effect of soybean germ phytosterols on $\mathrm{OH}^{*}$ radicals.

$\mathrm{OH}^{*}$. The $\mathrm{OH}^{*}$ scavenging ability of phytosterols increased from $36.11 \%$ to $54.93 \%$ with the concentration increasing from 300 to $700 \mu \mathrm{g} \mathrm{mL}{ }^{-1}$. The $\mathrm{EC}_{50}$ values of soybean germ phytosterols on $\mathrm{OH}^{*}$ scavenging were $582.31 \mu \mathrm{g} \mathrm{mL}^{-1}$, indicating their better $\mathrm{OH}^{*}$ scavenging ability than $V_{\mathrm{C}}\left(\mathrm{EC}_{50}=1200 \pm 1.13 \mu \mathrm{g} \mathrm{mL} \mathrm{m}^{-1}\right)$.

\subsection{Antioxidant activity of soybean germ phytosterols on $\beta$ - carotene protection}

The protective activity of soybean germ phytosterols against $\beta$ carotene oxidization was also determined (Fig. 4). If $\beta$-carotene is oxidized in the presence of light, air, heat, and linoleate-free radicals, it will lose its double bonds and become colorless. The results show that the soybean germ phytosterols effectively prevented the oxidative degradation of $\beta$-carotene. The

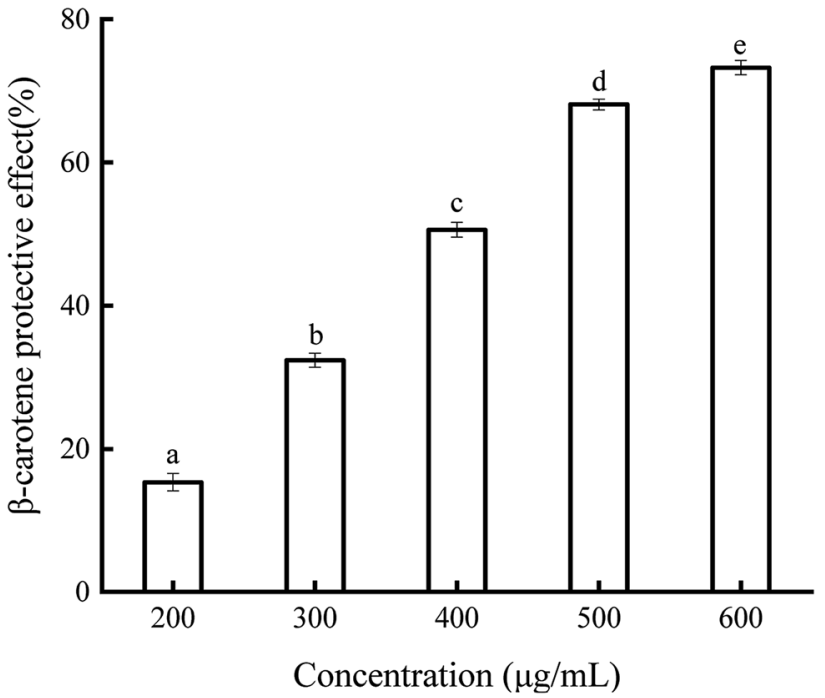

Fig. 4 Protective effect of soybean germ phytosterols against $\beta$ carotene bleaching.

increasing concentration (200-600 $\mu \mathrm{g} \mathrm{mL}^{-1}$ ) of soybean germ phytosterols was associated with the higher absorbance values of $\beta$-carotene $(15.34-73.21 \%)$ at $470 \mathrm{~nm}$. The $\mathrm{EC}_{50}$ values of soybean germ phytosterols and BHT on $\beta$-carotene protection were $372.70 \pm 1.36 \mu \mathrm{g} \mathrm{mL} \mathrm{m}^{-1}$ and $5.23 \pm 0.45 \mu \mathrm{g} \mathrm{mL} \mathrm{mL}^{-1}$, respectively.

\subsection{Antioxidant activity of soybean germ phytosterols in the oxidation of soybean oil}

The acid value is an indicator of the degree of hydrolysis of oils due to microorganisms, enzymes and heat during storage or processing. The effects of soybean germ phytosterols on the acid value changes of soybean oil at different temperatures were evaluated (Fig. 5). The results show that the AV of soybean oil was maintained at $0.10-0.15,0.10-0.20$ and $0.10-0.45 \mathrm{mg} \mathrm{KOH} /$ $\mathrm{g}$ at $60{ }^{\circ} \mathrm{C}, 120^{\circ} \mathrm{C}$, and $180{ }^{\circ} \mathrm{C}$, respectively, in 48 hours. This suggested that the acid value of soybean oil had no significant change at a lower temperature $\left(60^{\circ} \mathrm{C}, 120^{\circ} \mathrm{C}\right)$ with prolonged time but slightly increased at higher temperature $\left(180{ }^{\circ} \mathrm{C}\right)$, which might because the triacylglycerols decomposed when heated at a higher temperature for a long time. Moreover, we found that the addition of soybean germ phytosterols at any concentration had no obvious influence on the AV of the substrate oil as compared with the control.

The unsaturated fatty acids of oils will generate hydrogen peroxide products when oxidized. The peroxide value (POV) is used to evaluate the oil oxidation and rancidity degree. The effects of soybean germ phytosterols on the POV changes of soybean oil were examined (Fig. 6). The results show that oil samples with the addition of soybean germ phytosterols all had lower POV values as compared with the corresponding control under the same conditions, implying that the soybean germ phytosterols had antioxidant effects on lipids oxidation. Moreover, the POV of soybean oil samples decreased with increasing the amount of soybean germ phytosterols. For example, when 

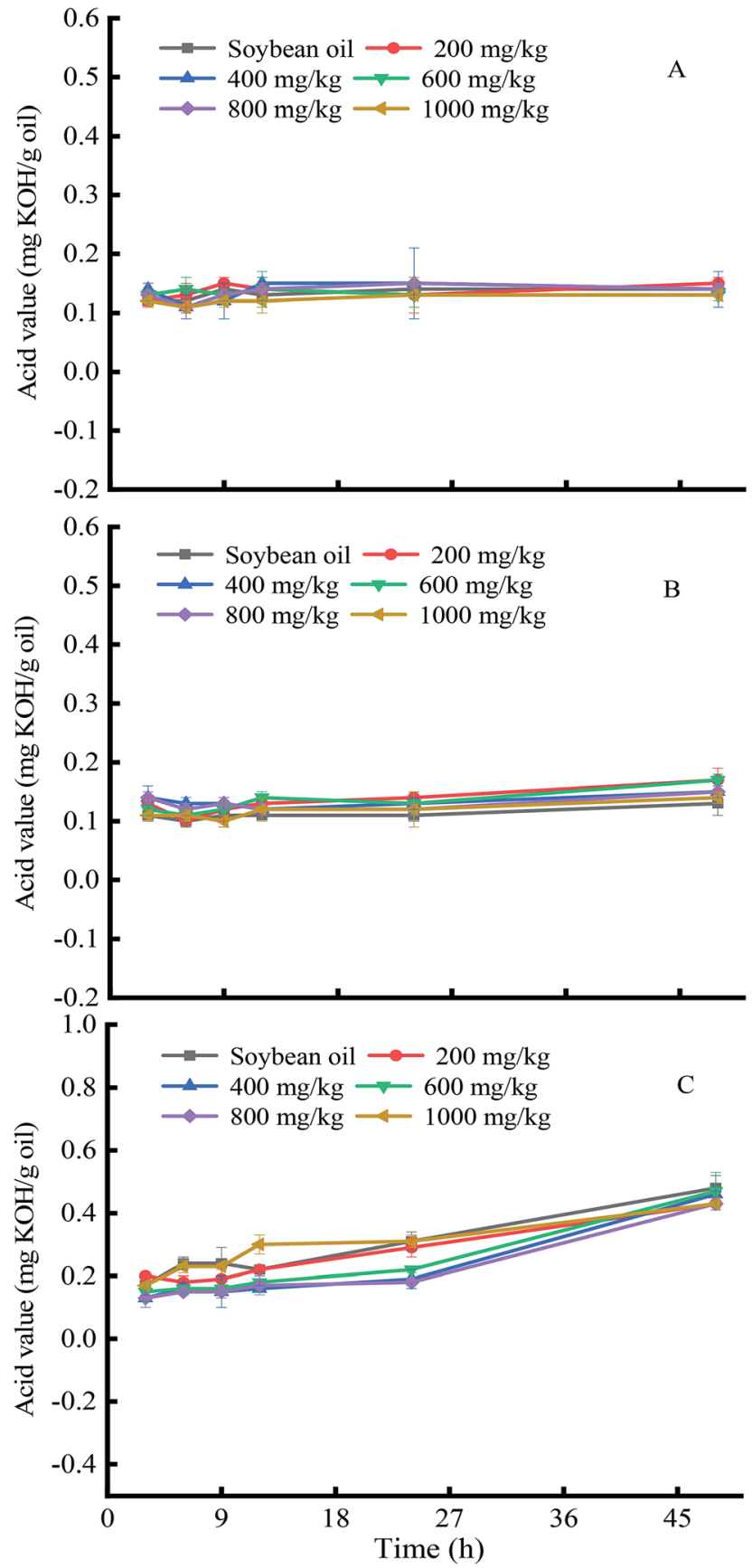

Fig. 5 The effects of soybean germ phytosterols on acid value changes in soybean oil at different temperatures. ((A), $60{ }^{\circ} \mathrm{C}$; (B), $\left.120^{\circ} \mathrm{C} ;(\mathrm{C}), 180^{\circ} \mathrm{C}\right)$.

the samples were heated at $60{ }^{\circ} \mathrm{C}$ for $48 \mathrm{~h}$ (Fig. 6A), the POV changes with increasing dosage were in the sequence of $22.35 \mathrm{mmol} \mathrm{kg}^{-1}$ (control) > $21.31 \mathrm{mmol} \mathrm{kg}^{-1}\left(200 \mathrm{mg} \mathrm{kg}^{-1}\right)>$ $15.56 \mathrm{mmol} \mathrm{kg}^{-1}\left(400 \mathrm{mg} \mathrm{kg}{ }^{-1}\right)>13.27 \mathrm{mmol} \mathrm{kg}^{-1}(600 \mathrm{mg}$ $\left.\mathrm{kg}^{-1}\right)>11.58 \mathrm{mmol} \mathrm{kg}^{-1}\left(800 \mathrm{mg} \mathrm{kg}{ }^{-1}\right)>6.69 \mathrm{mmol} \mathrm{kg}^{-1}$ $\left(1000 \mathrm{mg} \mathrm{kg}{ }^{-1}\right)$. We also found that the antioxidant ability of soybean germ phytosterols at a lower temperature $\left(60{ }^{\circ} \mathrm{C}\right)$ was better than that at a higher temperature $\left(120^{\circ} \mathrm{C}, 180^{\circ} \mathrm{C}\right)$. For instance, the POV difference between oil samples containing $1000 \mathrm{mg} \mathrm{kg}^{-1}$ soybean germ phytosterols (heated $48 \mathrm{~h}$ ) and
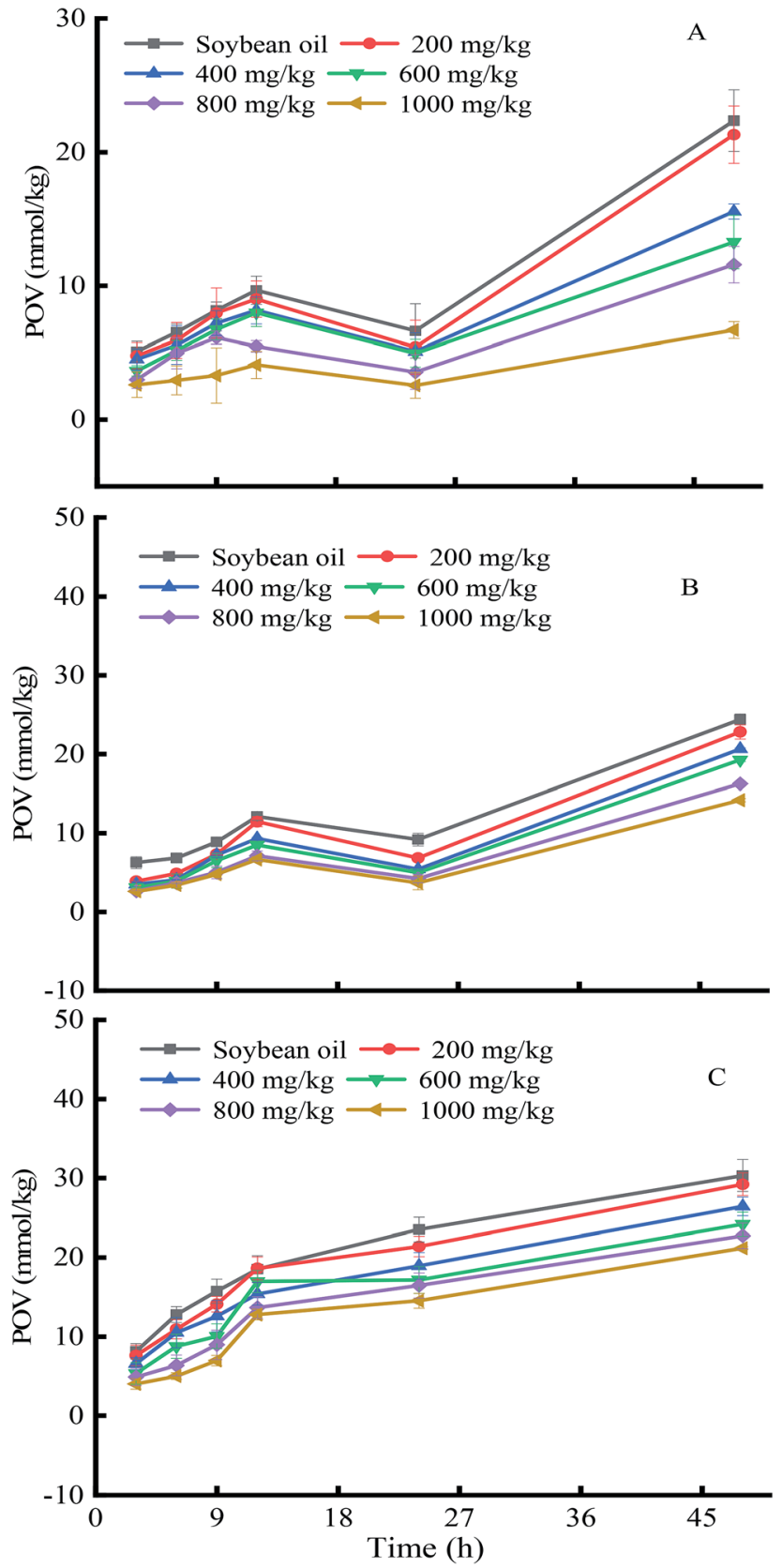

Fig. 6 The effects of soybean germ phytosterols on peroxidation value changes in soybean oil at different temperatures. ((A), $60^{\circ} \mathrm{C}$; (B), $120^{\circ} \mathrm{C}$; (C), $180^{\circ} \mathrm{C}$ ).

control was 15.66 at $60{ }^{\circ} \mathrm{C}$, while 10.22 and 9.14 at $120{ }^{\circ} \mathrm{C}$ and $180{ }^{\circ} \mathrm{C}$, respectively, probably because unsaturated fatty acids were much easier to oxidize at a higher temperature. Soybean germ phytosterols were also oxidized at elevated temperatures. ${ }^{36}$

Peroxides are unstable and will readily decompose into smaller molecules. The $p$-anisidine value $(p-\mathrm{AnV})$ is the index for evaluating the content of small molecular substances and is closely related to the rancidity degree of oils. The effects of soybean germ phytosterols on the $p$-anisidine value changes in soybean oil were measured (Fig. 7). The results show that the $p$ AnV of soybean oil increased continuously with prolonged time 


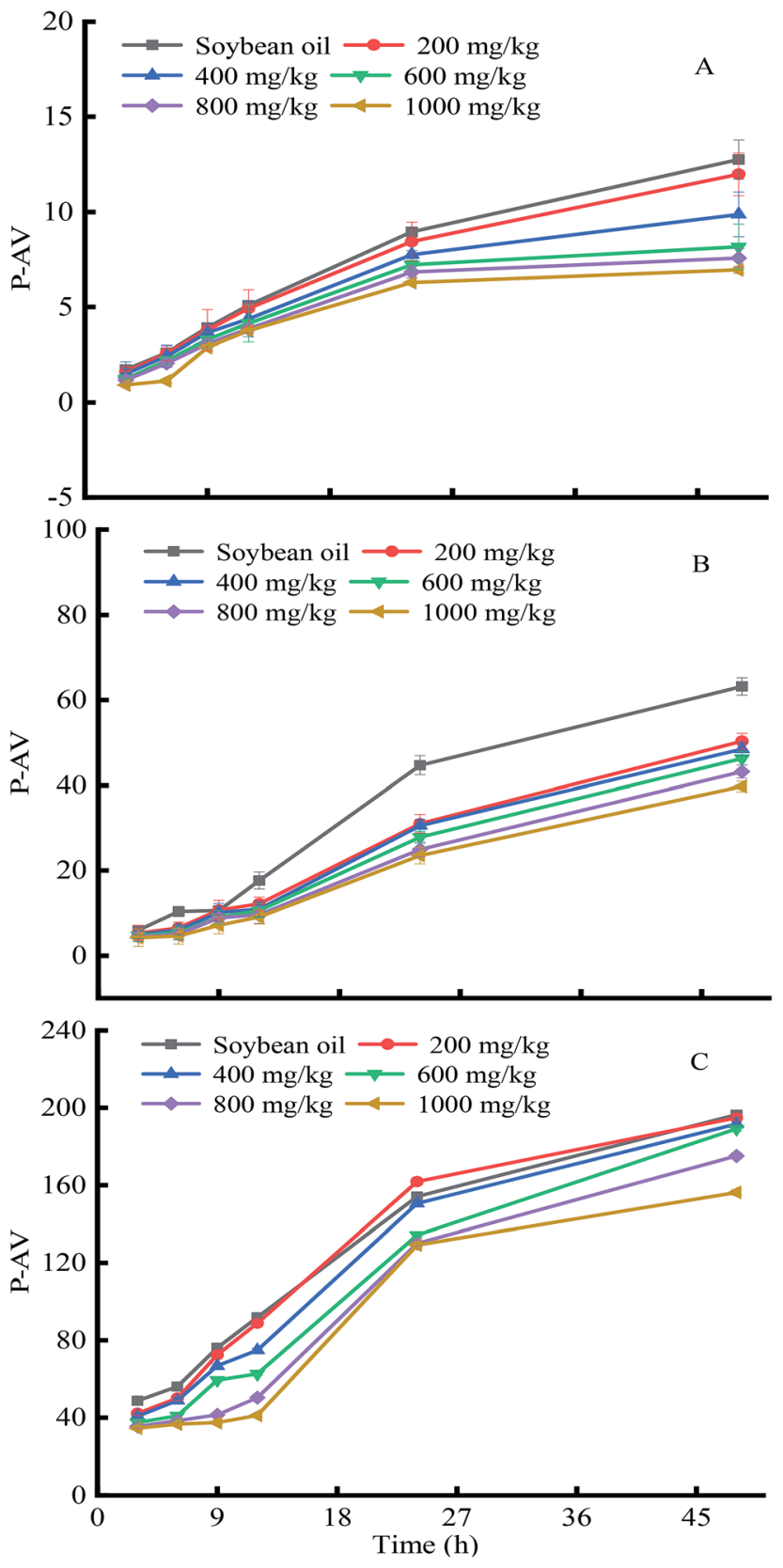

Fig. 7 The effects of soybean germ phytosterols on $p$-anisidine value changes in soybean oil at different temperatures. ((A), $60{ }^{\circ} \mathrm{C}$; (B), $120^{\circ} \mathrm{C}$; (C), $180^{\circ} \mathrm{C}$ ).

and elevated temperature $\left(180{ }^{\circ} \mathrm{C}, 34.60-194.86 ; 120{ }^{\circ} \mathrm{C}, 4.21-\right.$ $\left.50.33 ; 60{ }^{\circ} \mathrm{C}, 1.13-11.99\right)$, due to the gradual increase in peroxide decomposition into small molecules with increasing temperature. Obviously, the addition of the soybean germ phytosterols significantly decreased the $p$-AnV of the substrate oil in a dose-dependent manner as compared with the control, suggesting the potential antioxidation ability of soybean germ phytosterols. For example, when the oil samples were heated at $120{ }^{\circ} \mathrm{C}$ for $48 \mathrm{~h}$ (Fig. 7B), the $p$-AnV changes with increasing dosage were in the order of 63.20 (control) $>50.33\left(200 \mathrm{mg} \mathrm{kg}^{-1}\right)$ $>48.48\left(400 \mathrm{mg} \mathrm{kg}^{-1}\right)>46.29\left(600 \mathrm{mg} \mathrm{kg}^{-1}\right)>43.21(800 \mathrm{mg}$ $\left.\mathrm{kg}^{-1}\right)>39.73\left(1000 \mathrm{mg} \mathrm{kg}^{-1}\right)$.
The results of POV and $p$-AnV determination showed that soybean germ phytosterols had preferable antioxidant ability toward lipid oxidation. Some reports have indicated that 5- and 7-avenasterols, citrostadienol and vernosterol have the ability to inhibit the oxidative degradation of unsaturated fatty acids at higher temperatures. ${ }^{37-39}$ The underlying mechanism was the rapid formation of a free radical at the 29-allylic carbon on the phytosterols, leading to isomerisation to a relatively more stable tertiary free radical, so the oxidation chain reactions of fatty acids were interrupted. Moreover, Ashutosh found that sitosterol could significantly decrease triacylglycerol polymer formation in triolein and vegetable oils during frying. The underlying mechanism was attributed to the conversion of sterol into steradiene by the 1,2-elimination of water. ${ }^{40}$ The free radical reaction was terminated by the formed conjugated diene structure. These reports indicated that the antioxidant effects of plant sterols were greatly related to their own molecular structures, and the functional groups of phytosterols that had antioxidant effects were the ethylidene containing side chains and the conjugated dienes formed by the 1,2-elimination of water. Soybean germ phytosterols are composed of various individual groups ( $\beta$-sitosterol, stigmastenol, campesterol, citrostadienol, stigmasterol and $\Delta 7$-avenasterol), which might explain their excellent antioxidant ability in oil systems.

\section{Conclusion}

The present study characterized the composition of NE-SG and SD-SG and investigated the antioxidant activity of NE-SG phytosterols. The results show that the average contents of water, protein, crude fat, crude fiber and ash of NE-SG and SDSG were $8.23 \pm 0.11 \%, 40.47 \pm 0.10 \%, 11.65 \pm 0.14 \%, 6.20 \pm$ $0.09 \%, 4.79 \pm 0.14 \%$, respectively. The main fatty acids of soybean germ were linoleic acid, alpha-linolenic acid, palmitic acid and oleic acid. Most importantly, soybean germ is rich in phytosterols (NE-SGO, $3168 \mathrm{mg} / 100 \mathrm{~g}$ oil; SD-SGO, $3010 \mathrm{mg} /$ $100 \mathrm{~g}$ oil).

Soybean germ phytosterols had better antioxidant ability in soybean oil systems than in non-oil systems. Furthermore, their antioxidant ability at lower temperatures $\left(60{ }^{\circ} \mathrm{C}\right)$ was stronger than that at higher temperatures $\left(120\right.$ and $\left.180{ }^{\circ} \mathrm{C}\right)$ with prolonged oxidation time, indicating that soybean germ phytosterols could be used as antioxidants for preventing lipid oxidation in foods stored at a low temperatures for a long time.

\section{Conflicts of interest}

The authors claim that there is no conflict of interest in the present study.

\section{Acknowledgements}

The authors gratefully acknowledge the financial support from the Funds of National Natural Science Foundation of China (No. 31801501), Henan Scientific and Technical Problems (No. 182102110024) and Project of Henan University of Technology Excellent Young Teachers. 


\section{References}

1 S. L. Kim, J. E. Lee, Y. U. Kwon, W. H. Kim, G. H. Jung, D. W. Kim, C. K. Lee, Y. Y. Lee, M. J. Kim, Y. H. Kim, T. Y. Hwang and I. M. Chung, Food Chem., 2013, 136, 491500.

2 H. J. Wang and P. A. Murphy, J. Agric. Food Chem., 1996, 44, 2377-2383.

3 D. Y. Yu, W. Elfalleh, S. H. He, Y. Ma, L. Z. Jiang, L. Li, L. Z. Hu and J. N. Zhang, J. Am. Oil Chem. Soc., 2013, 90, 1551-1558.

4 G. Cravotto, B. Robaldo, A. Binello, F. Viola, S. Oliaro-Bosso and M. Avogadro, Eur. J. Lipid Sci. Technol., 2005, 107, 701705.

5 S. Saitoh, M. Urushibata, K. Ikuta, A. Fujimaki and H. Harada, J. Am. Oil Chem. Soc., 2000, 77, 419-424.

6 H. Kataoka, S. Saito, A. Itoh and T. Matsuo, Biosci., Biotechnol., Biochem., 2012, 76, 1413-1415.

7 H. Y. Zhu, J. N. Chen, Z. Y. He, W. J. Hao, J. H. Liu, E. Kwek, Y. M. Zhao, K. Y. Ma, W. S. He and Z. Y. Chen, Food Funct., 2019, 10, 1836-1845.

8 F. Bonina, C. Puglia, M. Avogadro, E. Baranelli and G. Cravotto, Arch. Pharm., 2005, 338, 598-601.

9 R. N. Yang, L. Xue, L. X. Zhang, X. F. Wang, X. Qi, J. Jiang, L. Yu, X. P. Wang, W. Zhang, Q. Zhang and P. W. Li, Foods, 2019, 8, 334.

10 J. Plat and R. P. Mensink, J. Am. Coll. Cardiol., 2005, 96, 1522.

11 J. N. Chen, R. Jiao, Y. Jiang, Y. L. Bi and Z. Y. Chen, J. Agric. Food Chem., 2014, 62, 675-681.

12 V. Z. Rocha, R. T. Ras, A. C. Gagliardi, L. C. Mangili, E. A. Trautwein and R. D. Santos, Atherosclerosis, 2016, 248, 76-83.

13 P. J. Jones and S. S. Abumweis, Curr. Opin. Clin. Nutr. Metab. Care, 2009, 12, 147-151.

14 T. Ishizaki, Y. Hara, K. Yamada, H. Sato and I. Tashima, Nippon Eiyo Shokuryo Gakkaishi, 2005, 58, 11-16.

15 M. F. Ramadan and J.-T. Moersel, J. Food Compos. Anal., 2006, 19, 838-842.

16 Y. Yoshida and E. Niki, J. Nutr. Sci. Vitaminol., 2003, 49, 277280.

17 AOAC, Official methods of analysis, Association of official analytical chemists, Washington, DC, 16th edn, 1995.

18 D. H. Spackman, W. H. Stein and S. Moore, Anal. Chem., 1958, 30, 1190-1206.
19 Official Method and Recommended Practices of the AOCS, American Oil Chemists Society, Champaign, IL, USA, 5th edn, 1998.

20 B. D. Oomah, S. Ladet, D. V. Godfrey, J. Liang and B. Girard, Food Chem., 2000, 68, 187-193.

21 W. Liu, G. H. Lu, G. L. Yang and Y. L. Bi, Fuel, 2019, 242, 133139.

22 AOCS Official Methods and Recommended Practices, American Oil Chemists' Society, 2011, ch. 6-91.

23 F. J. Morales and S. Jimenez-Perez, Food Chem., 2001, 72, 119-125.

24 L. Chen and G. L. Huang, Int. J. Biol. Macromol., 2019, 128, 14.

25 H. E. Miller, J. Am. Oil Chem. Soc., 1971, 48, 91-92.

26 Official methods and recommended practices, American Oil Chemists' Society: AOCS Press, 6th edn, 2011.

27 R. S. Attia and H. A. Abou-Gharbia, J. Food Sci. Technol., 2011, 8, 31-39.

28 S. Harrabi, A. St-Amand, F. Sakouhi, K. Sebei, H. Kallel, P. M. Mayer and S. Boukhchina, Food Chem., 2008, 111, 115-120.

$29 \mathrm{FAO} / \mathrm{WHO} / \mathrm{UNU}$, Energy and protein requirements, WHO Tech. Rep. Ser. No. 1985, 724.

30 Y. M. Cui, P. F. Hao, B. J. Liu and X. H. Meng, Food Chem., 2017, 233, 77-84.

31 M. L. Wang, P. Raymer, M. Chinnan and R. N. Pittman, Biomass Bioenergy, 2012, 39, 336-343.

32 B. Jaselskis, N. L. Stemm and W. D. Johnston, Talanta, 1982, 29, 54-56.

33 H. Y. Zhu, J. N. Chen, Z. Y. He, W. J. Hao, J. H. Liu, E. Kwek, Y. M. Zhao, K. Y. Ma, W. S. He and Z. Y. Chen, Food Funct., 2019, 10, 1836.

34 S. B. Kedare and R. P. Singh, J. Food Sci. Technol., 2011, 48, 412-422.

35 R. Farhoosh, M. H. Tavassoli-Kafrani and A. Sharif, Food Chem., 2011, 126, 583-589.

36 L. Soupas, L. Juntunen, A.-M. Lampi and V. Piironen, J. Agric. Food Chem., 2004, 52, 6485-6491.

37 M. H. Gordon and P. Magos, Food Chem., 1983, 10, 141-147.

38 P. J. White and L. S. Armstrong, J. Am. Oil Chem. Soc., 1986, 63, 525-529.

39 P. S. Yan and P. J. White, J. Agric. Food Chem., 1990, 38, 19041908.

40 A. Singh, Food Chem., 2013, 137, 62-67. 